\title{
3
}

\section{An Integrated Approach Providing Scientific and Policy-Relevant Insights for South-West Bangladesh}

\author{
Robert J. Nicholls, Craig W. Hutton, Attila N. Lázár, \\ W. Neil Adger, Andrew Allan, Paul G. Whitehead, \\ Judith Wolf, Md. Munsur Rahman, Mashfiqus Salehin, \\ Susan E. Hanson, and Andres Payo
}

\subsection{Introduction}

As explained in Chap. 1, deltas are vulnerable to sea-level rise and climate change, reflecting their low elevation which is largely controlled by the present sea level (Ericson et al. 2006). Bangladesh, in particular, has been identified as an impact hotspot for sea-level rise in multiple studies over several decades (e.g. Milliman et al. 1989; Warrick et al. 1993; Huq et al. 1995; World Bank 2010). However, a range of other drivers are important in all

R. J. Nicholls $(\bowtie) \bullet A$. N. Lázár • S. E. Hanson

Faculty of Engineering and the Environment and Tyndall Centre for Climate Change Research, University of Southampton, Southampton, UK

C. W. Hutton

Geodata Institute, Geography and Environment, University of Southampton, Southampton, UK

W. Neil Adger

Geography, College of Life and Environmental Sciences, University of Exeter, Exeter, UK 
deltas including Bangladesh, such as regional factors (especially catchment management, socio-economic development and governance quality) and numerous delta plain factors (e.g. sediment starvation, subsidence, land use change, ill-planned interventions) (see Woodroffe et al. 2006; Syvitski et al. 2009; Tessler et al. 2015; Day et al. 2016). Collectively, this threatens an increase in a range of hazards such as flooding, inundation, salinisation and erosion, in turn impacting delta residents' vulnerability, livelihoods and food security. To fully analyse these risks an integrated or systems analysis of the delta is required (Nicholls et al. 2016; Chap. 4).

Such an analysis of south-west coastal Bangladesh (henceforth coastal Bangladesh) situated within the Ganges-Brahmaputra-Meghna (GBM) delta (Chap. 4, Figs. 4.1 and 4.2) is described in this book. The overall aim of this research is twofold. Firstly, it is to understand coastal Bangladesh through the lens of ecosystem services and associated livelihoods. Secondly, it is to make this information available in a form that is suitable for relevant decision makers. This requires linking science to policy at the landscape scale. Chapter 2 analysed how ecosystem services relate to poverty and its alleviation in deltas, and its development and environmental management implications. The aim of this chapter is to

\section{A. Allan}

School of Law, University of Dundee, Dundee, UK

P. G. Whitehead

School of Geography and the Environment, University of Oxford,

Oxford, UK

J. Wolf

National Oceanographic Centre, Liverpool, UK

Md. Munsur Rahman • M. Salehin

Institute of Water and Flood Management, Bangladesh University of Engineering and Technology, Dhaka, Bangladesh

A. Payo

British Geological Survey, Keyworth, Nottingham, UK 
review the scientific insights concerning the delta system and consider their relevance and utility to national policy. The issue of transferability of this understanding to other deltas is also briefly considered.

Integration and policy relevance was at the heart of the research design, necessitating ongoing discussions among the research team from the commencement of this research. Making it a core theme contributed to the success of integration. Consistency is also important and coordination across the project ensures that all the components follow a common conceptual model and set of narratives about future conditions. Chapter 4 outlines the integrated methodology which included scenario development, stakeholder analysis and engagement (Chaps. 9, 10, 11 and 12), socio-economic analysis and bespoke household surveys (Chaps. 19, 20, 21, 22 and 23) and biophysical modelling of the range of processes (Chaps. 13, 14, 15, 16, 17 and 18) and supporting ecosystem services (Chaps. 24, 25 and 26).

Building on this integrated framework, a dedicated integrated assessment model was built to (i) harmonise across the different scales and models, (ii) provide practical run times and (iii) address feedbacks by tightly coupling the individual assessment models. This led to the development of the Delta Dynamic Integrated Emulator Model $(\triangle \mathrm{DIEM})$ (Fig. 3.1 and Chap. 28). $\triangle \mathrm{DIEM}$ is designed to assess the potential social-ecological trajectories of coastal Bangladesh, including the role of different development and adaptation choices. Hence policy choices are an explicit input to the analysis. While $\triangle D I E M$ is a sophisticated software tool, its development has also facilitated major discussion and learning between project participants from diverse disciplinary backgrounds. $\triangle \mathrm{DIEM}$ and the wider project research encapsulate learning, coordination and cooperation amongst the diverse project partners. There is also ongoing engagement with national level stakeholders engaged in strategic planning. The premise of this engagement is that, in this case, influencing national policy maximises impact of the research, and this required us to understand this national policy context. Hence the research theory of change revolves around stakeholder engagement with national stakeholders to promote understanding, usefulness, trust and ownership concerning the approach and results. As explained in Chap. 9, these social dimensions of integration are expressed as an 'iterative learning process' (see also Chap. 4, Fig. 4.5) where 

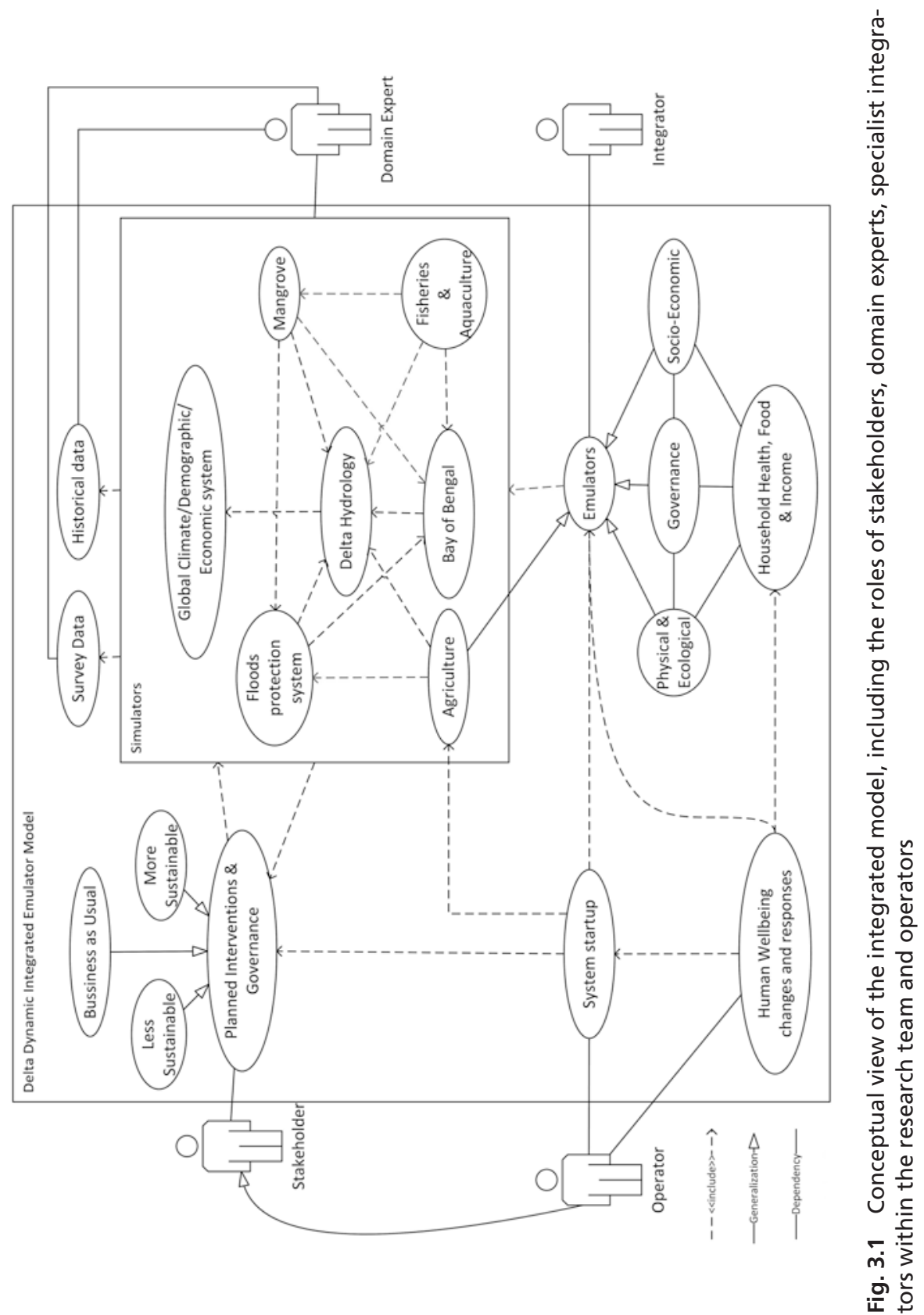
the model design and development is coupled to repeated stakeholder engagement and co-production of scenarios and results.

The dynamic nature of the policy environment within Bangladesh also needs to be recognised and addressed as this influences the approach and outcome of the research described (see Chap. 6). Bangladesh has an aspiration to be a middle-income country by 2030 and follows a five-year planning cycle coordinated by the Planning Commission, Government of Bangladesh with the last plan covering the period 2016 to 2020, inclusive (GED 2015). A new Perspective Plan coincided with the research engagement. That Plan laid out a national development pathway to 2021 to coincide with the 50th anniversary of the founding of Bangladesh (GED 2012). Subsequently, the policy environment evolved rapidly with the development of the Bangladesh Delta Plan 2100 (BDP2100) as a living and integrated national planning document (BanDuDeltAS 2014). It is inspired by international experience, especially the Delta Commissie (2008) and the subsequent creation of the Delta Commission and associated plans in the Netherlands (Van Alphen 2016). Globally, the Sustainable Development Goals (SDGs) have also been developed (UN 2015) within the lifetime of the project and are being widely applied in Bangladesh (e.g. GED 2017). With the Prime Minister of Bangladesh becoming a member of the United Nations High-Level Panel on Water (for SDG 6), Bangladesh has bolstered its SDG-related activities, including developing concept papers and action plans. The stakeholder engagement strategy was kept flexible and the emergence of the BDP2100 in particular created a stronger environment of stakeholder engagement facilitated by the Planning Commission, enhancing the development and application of this research.

This chapter is structured as follows. Section 3.2 considers key insights that emerged from the research described in this book and their policy implications. It considers the present situation, potential trends and ecosystem services, including the integrated assessment, policy implications, and briefly the SDGs. Section 3.3 discusses the implications for the future of coastal Bangladesh and sets the research into a broader context. Section 3.4 provides conclusions. 


\subsection{Key Insights Concerning Coastal Bangladesh}

\subsubsection{Present Status}

Bangladesh is perceived internationally to be significantly constrained by challenges linked to climate change and sea-level rise (Roy et al. 2016). Certainly temperatures and sea levels are slowly rising and the delta is subsiding, which are adverse trends (Hijioka et al. 2014). Further, there is the longstanding threat of cyclones, although preparedness has improved dramatically since the 1991 cyclone, greatly reducing loss of life (Lumbruso et al. 2017). But the trajectory of development and wellbeing in Bangladesh is the outcome of demographic change, the urbanisation trends, the rise of manufacturing and regional geopolitics, coupled to environmental constraints or challenges, as recognised at the core of the analysis in this book.

The national population of Bangladesh increased fourfold between 1950 and 2013, from 38 to 157 million and is projected to exceed 200 million by 2050 (UN 2013). There is strong ongoing urbanisation exemplified by growth of Dhaka from about 300,000 people in 1950 to a world city of over 18 million people in Greater Dhaka today. Most data sources show significant increases in per capita GDP: for example, according to the World Bank from US\$410 in 2000 to US\$1,360 in 2016. The direct sources of economic growth are changes to the structure of the economy: growth in (i) manufactured exports especially clothing, (ii) overseas remittances and (iii) non-farm employment (Chap. 12). The historical trends and trade-offs between provisioning and regulating ecosystem services in Bangladesh (Chap. 5) have already been emphasised in Chaps. 1 and 2. Production of agriculture and fisheries has boomed, but at the cost of environmental quality and regulation. This demonstrates the strong temporal dynamics of ecosystem services and important tradeoffs that need to be considered in environmental management. Linked to this is one significant land use change: the significant expansion of saline shrimp farming replacing rice fields north of the Sundarbans (Chap. 20). The growth of shrimp-based aquaculture appears to be associated with both high dry season salinity and the proximity of a substantial settlement 
with good access and processing facilities (in this case Khulna). These changes might be viewed as a useful adaptation to increasing salinity intrusion in the region, with shrimp providing a new export commodity. However, brackish water aquaculture also has environmental impacts and consequences for land tenure, livelihood displacements and income loss, food insecurity and health, rural unemployment, social unrest, conflicts and forced migration (Chap. 20).

Even though the national population is rising in Bangladesh, the coastal population is declining, reflecting net migration to urban areas. Chapter 19 estimates that the present study area population of 14 million could decline to 11 to 13.5 million by 2050 . This reflects multiple drivers of migration and sea-level rise, and climate change do not appear to be direct drivers to date (Roy et al. 2016), although anecdotally this is often reported as such in the media.

\subsubsection{Potential Trends for Coastal Bangladesh}

A range of potential trends are apparent for coastal Bangladesh over the next 50 to 100 years, with climate change being a major driver of these changes (Table 3.1). However, other human-induced trends are occurring, and these might be more important than climate change in some cases. For example, climate change will intensify the monsoon (Chap. 11) with greater run-off during the wet season and less freshwater flow during the dry season (Whitehead et al. 2015a, b). The development of major catchment infrastructure in neighbouring upstream countries (e.g. interlinking river project in India (National Water Development Agency 2017)) may lead to further reduction in dry season flows. The potential magnitude of these reductions is much larger than those due to climate change alone, raising challenges of intergovernmental coordination between states on the GBM basin (Yasuda et al. 2017).

In addition to water supply, this research suggests that due to climate change alone the supply of fluvial sediment being delivered to the GBM delta is likely to increase by around 50 per cent by 2100 (Chap. 15). However, catchment changes are likely to have the opposite effect, and a net reduction in the catchment sediment supply to the delta appears 
Table 3.1 Key potential trends for coastal Bangladesh to 2100

\begin{tabular}{cc}
\hline & Key trend \\
\hline Climate & The monsoon is expected to intensify with higher peak run-off \\
down the Ganges, Brahmaputra and Meghna. Similarly dry \\
season flows are expected to decline due to climate change \\
Climate-induced sea-level rise will be enhanced by subsidence, \\
giving greater amounts of relative sea-level rise \\
Fluvial flooding (during the monsoon) and surge flooding (due \\
to cyclones) are expected to intensify due to climate change \\
and relative sea-level rise unless flood management is \\
upgraded and improved \\
Increased salinisation of the coastal waters is expected due to \\
relative sea-level rise \\
The large sediment supply to the delta will increase \\
significantly due to climate change \\
Sediments/ \\
freshwater \\
supply \\
greater potential to reduce freshwater flow and sediment \\
delivery, with particular concern for freshwater supply during \\
the dry season \\
Changes in the primary productivity in the Bay of Bengal \\
appear to be small \\
Agriculture will become increasingly stressed in the region, \\
especially during the dry season. Salinisation and higher \\
temperatures play an important role \\
While primary productivity and fisheries can be maintained \\
with small reductions under sustainable management, \\
fisheries are in danger of collapse under less sustainable \\
management regimes \\
The Sundarbans are more resilient to sea-level rise than \\
suggested in earlier assessments. Even under the highest \\
relative sea-level rise scenario (about 1.7 m), it is estimated \\
that more than $60 \%$ of the area will survive to 2100. \\
However, the constituent mangrove species in the \\
Sundarbans will change towards more salt-tolerant species \\
and become less diverse \\
\hline
\end{tabular}

more likely. This is a critical factor as sediment has built the delta over millennia and reduction in sediment supply is seen to threaten many deltas globally (Ericson et al. 2006; Syvitski et al. 2009), for example, the Mekong delta (Chapman et al. 2016). More effort to understand the future catchment sediment budget and delta level morphodynamics in the GBM delta could pay dividends, especially in terms of managing sediments and sedimentation in beneficial ways at the delta scale (Angamuthu 2017). 
Flooding is a defining issue in coastal Bangladesh and nationally (Chaps. 8 and 16). There are several sources of flooding, including fluvial, tidal and cyclone-induced floods, as well as compound floods from multiple sources at the same time. Given the importance of compound floods, basic research on understanding compound flooding in Bangladesh may well bring dividends in adaptation planning (cf. Wahl et al. 2015). In addition to these flood sources, the extensive polder system and their embankments across the study area must be considered. The potential magnitude of land inundation due to all forms of flooding is aggravated over the twenty-first century by relative sea-level rise and in some cases larger upstream river flows. For the scenarios considered, the changes in cyclone-induced flooding are greater than those for fluvial flooding. The flood analysis demonstrates that the effects of sea-level rise are not simple inundation as assumed in earlier analyses (e.g. Milliman et al. 1989; Huq et al. 1995). This reflects the existence of extensive polders and embankment systems as well as the areas outside the polders, such as the Sundarbans, which can accrete sediment with sea-level rise (see Chap. 26).

Salinity is a defining issue in coastal Bangladesh as high salinities of the rivers and estuaries penetrate inland degrading the water resources and agriculture (Chaps. 17 and 18). There are spatial and temporal gradients with the saltiest river waters in the western estuarine section and the Sundarbans forest and a strong seasonal signal in the freshwater distribution controlled by variable river discharge from the monsoon to the dry season. Under all future projections of freshwater input and oceanic changes, salinity is predicted to increase in the river channels. This increase is more pronounced in the central and western estuarine section with important implications for agriculture, shrimp farming and local wellbeing. For soil salinity, inter-seasonal climate variability appears to determine if this increases or declines relative to the present (Payo et al. 2017).

\subsubsection{Trends in Ecosystem Services}

Agriculture is the single most important provider of ecosystem services to the people of coastal Bangladesh. Income from agriculture is currently constrained by the limited availability of good quality irrigation water in the dry season, access to markets and the cost of fertilisers. It is reviewed 
further using the $\triangle$ DIEM results in Chap. 28. However, future monsoon variability and high temperatures during the dry season can hinder crop productivity more than salinity up to 2050 (Chap. 24).

Climate change is projected to reduce fish production in the Bangladesh Exclusive Economic Zone by up to ten per cent (Chaps. 14 and 25). These impacts are larger for the two major species (Hilsa shad and Bombay duck). Overfishing combined with climate change could reduce Hilsa catches by up to 90 per cent by 2050. In contrast, good management can maintain sustainable catches over the same period.

The Sundarbans mangrove forest is critical in providing ecosystem services to the poor (Chap. 26). The Sundarbans also provide significant buffering from floods to landward regions during cyclones augmenting traditional flood defences. Mangroves decline in area and show species change, but remain an important land cover providing important benefits under all the scenarios considered to 2100 . This is a more optimistic outcome than previously widely reported (Hijioka et al. 2014).

\subsection{Integrated Assessment Using the Delta Dynamic Integrated Emulator Model}

$\triangle \mathrm{DIEM}$ has simulated the ecosystem service and livelihood futures of coastal Bangladesh to 2050 for a range of scenarios (Chap. 28). This shows a more complex set of behaviours than the uncoupled analysis. The region develops under all the scenarios considered, but the rate of development depends on the future population dynamics and the economic situation. Present agriculture-based livelihoods are constrained by land availability, high dry season salinity and agro-economics. Monsoon rains supply adequate water to grow one main season rice crop, but farmers' incomes are constrained by the market price for rice compared with the direct agriculture costs (i.e. this allows little or no profit). Lack of fresh water is a constraint for irrigated crops in the drier months. The use of low irrigation water quality (i.e. too high salt content) contributes to soil salinisation reducing farm production potential. Future dry season crop production is also likely to be constrained by drought (i.e. lack of water 
and high air temperature). Fortunately, the development of drought- and salt-tolerant varieties of rice and other crops is progressing and is essential under the future scenarios considered here.

For the average household, socio-economics is decoupled from climate and environmental change, although this is strongly related to future population dynamics and the poorest remain dependent on environmental services. This suggests that non-ecosystem services-based income sources can maintain well-being in coastal Bangladesh even if the traditional fish- and farm-based livelihoods become less profitable. Policies setting advantageous market conditions for farmers and fishers, creating new off-farm job opportunities and establishing new infrastructure to connect people to natural resources and markets would have a significant impact on the future welfare of the study area. However, even though the economy and human well-being can grow under appropriate governance and social policies, hazards and environmental change will still have a detrimental effect on food security in Bangladesh. For example, soil salinity, together with household socio-economic characteristics, is one of the main explanatory variables of food security for coastal households (i.e. increasing salinity leads to reduced food security) regardless of wealth levels (Szabo et al. 2015). As already noted, soil salinisation will continue to increase after 2050, and these changes will likely accelerate. Furthermore, cyclones are widely expected to intensify in the future (Church et al. 2013) (Chap. 14) which is highly detrimental when coupled with relative sea-level rise. Hence in addition to development to 2050 , strategic adaptation measures to deal with climate change are essential in the longer term.

\subsection{Policy Implications}

Table 3.2 summarises some of the key policy implications of this research. There are several immediate priorities related to the current status of ecosystem services. There are also a number of longer-term measures where research and demonstration activities are required now, so that full implementation is available in a few decades. Working with sedimentation and 
Table 3.2 Key policy implications of changing ecosystem services and related issues for coastal Bangladesh

\begin{tabular}{|c|c|}
\hline & Policy implication \\
\hline Short term & $\begin{array}{l}\text { Current trends in ecosystem services are not } \\
\text { sustainable, and an immediate policy response is } \\
\text { required, especially for regulating ecosystem services } \\
\text { Fisheries management requires urgent attention } \\
\text { Training of farmers and fishers for good management } \\
\text { practices are essential } \\
\text { Implementation of policy across multiple sectors and } \\
\text { scales will be challenging in the light of limited legal } \\
\text { and coordinated institutional capacity }\end{array}$ \\
\hline $\begin{array}{l}\text { Longer term (although } \\
\text { research and } \\
\text { demonstration } \\
\text { activities are required } \\
\text { now) }\end{array}$ & $\begin{array}{l}\text { The potential increases in fluvial and coastal flooding } \\
\text { over the twenty-first century require a strategic } \\
\text { adaptation response } \\
\text { The possible role of sediment-based adaptation } \\
\text { should be considered-that is controlled } \\
\text { sedimentation to build land elevation mimicking the } \\
\text { natural processes that build deltas. This provides a } \\
\text { strategy which can maintain coastal Bangladesh into } \\
\text { an uncertain future providing sufficient sediment is } \\
\text { available } \\
\text { Continued development of climate-resistant crop } \\
\text { varieties (salt, temperature, etc.) will be essential to } \\
\text { sustain agriculture in coastal Bangladesh } \\
\text { The resilience of the Sundarbans to sea-level rise } \\
\text { suggests more exploration of nature-based solutions, } \\
\text { such as green mangrove belts would be prudent }\end{array}$ \\
\hline
\end{tabular}

nature-based solutions is innovative and offers great potential. The scale of implementation should also be noted as this will be needed at the delta scale. These ideas are fully consistent with the Bangladesh Delta Plan 2100. These conclusions should also be seen in the context of the existing legal and institutional situation that faces challenges in coordinating policy implementation across ecosystem services and livelihood enhancement in coastal Bangladesh (Chap. 6). 


\subsection{Relevance to the Sustainable Development Goals}

In the period of this research, the SDGs have been developed and adopted globally as development targets for 2030 (UN 2015). They comprise a set of 17 'Global Goals' with 169 targets between them and are encouraging global activity on how to achieve and how to measure these achievements (Szabo et al. 2016), including in Bangladesh. The SDGs have essential and ambitious targets that are important today. This is reflected in the short timescale aiming to achieve most of these goals by 2030. However, 2030 is too close to experience significant climate and environmental changes, and therefore, the long-term needs for adaptation are not explicitly embedded in the SDGs.

While not designed explicitly to support the SDGs, the approaches described in this book have great potential in this regard. In particular they can provide interdisciplinary insights on several SDGs and consider both short-term and long-term trends and their context. This was discussed and supported in a two-day meeting presenting the results in this book, held at the Royal Society, London in November 2016. These approaches already provide a wide range of indicators across the societal and environmental domains, which may be more suitable than many simple measured indicators used previously. Trends in river flows, sediment fluxes and coastal salinity are three relevant trends discussed in this book that relate to various SDGs, and especially SDG 6 (Clean water and sanitation). Furthermore, the methods are flexible and can be developed and targeted as required.

\subsection{Discussion}

The integrated approach that has been adopted in this research has yielded both scientific and policy-relevant insights. It shows that there is a need for adaptation to climate change in coastal Bangladesh, as widely recognised, but this adaptation needs to be set into the wider context of the developing Bangladesh society. Given the large flood plain areas, 
adaptation and planning for increased flooding is essential. More consideration needs to be given to understanding and predicting embankment breaching as this will become more likely over time if no planning is undertaken. Upgrading the embankments, as already proposed in the Bangladesh Delta Plan 2100, is one approach, combined with other actions such as improved warning systems (Dasgupta et al. 2014). More fundamentally there is a need to develop more sustainable long-term delta-scale management techniques that utilise sediments and sedimentation in new ways. This is large-scale controlled (or engineered) sedimentation within polders as well as working with morphodynamic processes to build land elevation and sustain natural ecological functions such as fisheries spawning (Amir et al. 2013; Auerbach et al. 2015). 'Tidal river management' has only been employed locally to date, and to be successful would require both fundamental scientific investigation of morphodynamic processes and the development of innovative large-scale engineering application. In addition to the technical dimensions of these policies, the social dimensions will also need to be considered such as education and training, infrastructure development and targeted financial support to the poorest of the poor. Ignoring these social dimensions is likely to impede or stop their application.

In addition to the insights obtained, the method itself is worthy of consideration. The hybrid integrated framework and method has allowed a move away from an ad hoc external expert or purely indicator-based approach. It provides an opportunity not only to explore the interactions between domains of knowledge as diverse as oceanographic modelling and perception-based assessments of well-being but also to incorporate the views of stakeholders throughout in ways which maintain the relevance and credibility of the findings, despite their complexity. The assumptions are explicit and have been debated and challenged as part of this co-production process, and changed as knowledge has grown and the detailed questions being posed have evolved with this understanding. Hence, it provides an explicit framework to analyse the problem and provide spatially explicit output. In particular, it forces the users to identify, consider and explore the limits to knowledge of the relevant system. Such reflection is critical in problems where gaps and limits in current knowledge need to be acknowledged and addressed. It should be noted 
that $\triangle \mathrm{DIEM}$ and its associated approaches continue to be developed and applied in partnership with the Bangladesh Delta Plan 2100, including assessing specific proposals.

This approach depends upon systems analysis and simulation modelling. Given the difficulty of predicting change in all of the systems considered here, such modelling could be regarded as being almost naïve. The limits to what is represented are recognised in the models, but the aim was to represent all the relevant processes and their interactions; many of the insights emerged within the integrated modelling. This facilitated development of conceptual ideas, promoted detailed discussion across discipline boundaries and resulted in usable algorithms and software. As increased understanding is obtained, algorithms can be modified or replaced. Even though this particular funded research project is complete, the process is not at an end. As experience is gained, the exploration of the complexities, interdependencies and uncertainties of coastal Bangladesh, and more widely, will continue. This includes considering a wide range of possible strategies for development linking to the Bangladesh Delta Plan, for example.

Building these types of co-produced analytical tools represents a significant amount of effort and resource, but the new insights, capacity building, scientific and policy applications and understanding generated justify this approach fully. Further, the ambitious policy processes such as the Bangladesh Delta Plan 2100 demand the development of these types of tools. In the Netherlands, the Delta Commissie (2008) led to the development of the national Delta Model (Prinsen et al. 2015; Van Alphen 2016), while in the Mississippi delta, restoration activities have led to the Coastal Master Plan Model (Coastal Protection and Restoration Authority 2013). While less common in developing country settings, these tools are still required to support developing management and development plans. Hence, these methods could be applied more widely across other deltas, as many issues are common. The methods could be extended to consider other issues such as cities and urbanisation, which are critical issues in most populated deltas. In principle the methods described are not delta-specific and could be applied in other coastal and even non-coastal contexts where strong social-ecological coupling exists. As such, the approach is flexible to user needs. 


\subsection{Conclusions}

This chapter has considered the insights provided by a new integrated framework for analysing the future of coastal Bangladesh. The approach is modular allowing incremental improvement. It is also based on a participatory approach, and this was a key element in the successful engagement with national stakeholders and capturing their thinking within the analysis. The results show three key high-level interacting challenges for the future trajectory of coastal Bangladesh over the coming 30 years: continued potential decline in ecosystem services, persistent poverty and the interacting challenges of climate change with adaptive responses and measures.

First, the modelling results and the informed perspective of key stakeholders suggest that the future is more sensitive to policy interventions and responses to them than climate change; favourable development scenarios could transform Bangladesh towards sustainable development paths in a 30-year timescale. However, severe climate events such as cyclones are likely to represent a potential brake on such development. Second, ecosystem services diminish as a proportion of the economy with time, continuing historic trends. Third, significant poverty persists in some locations under all scenarios with specific populations remaining vulnerable, left behind and in need to direct assistance and policy targeting. These include populations without ownership to land that are directly dependent on informal labour markets and those dependent on the informal economy more generally (see also Chap. 2).

Beyond 2050, the effect of climate change may be much larger, and concerns about higher temperatures, changing hydrology and run-off, sea-level rise and more intense cyclones are important. Strategic adaptation to these challenges is essential, and preparation is required now. In this regard, innovative measures such as working with sedimentation processes and the creation of mangrove buffer zones deserve development and trial implementation at the large scale.

The Government of Bangladesh is promoting the application of these approaches and is evaluating several of proposed interventions with the Bangladesh Delta Plan 2100. This type of practical application is the best way to learn about application and is continuing the iterative learning loop on which the project methodology is based. 


\section{References}

Amir, M.S.I.I., M.S.A. Khan, M.M.K. Khan, M.G. Rasul, and F. Akram. 2013. Tidal river sediment management-A case study in southwestern Bangladesh. International Journal of Environmental, Chemical, Ecological, Geological and Geophysical Engineering 7 (3): 176-185.

Angamuthu, B. 2017. The morphodynamic characteristics of a mega tidal delta over decadal to centennial timescales: A model-based analysis. Unpublished $\mathrm{PhD}$ thesis, University of Southampton.

Auerbach, L.W., S.L. Goodbred, D.R. Mondal, C.A. Wilson, K.R. Ahmed, K. Roy, M.S. Steckler, C. Small, J.M. Gilligan, and B.A. Ackerly. 2015. Flood risk of natural and embanked landscapes on the Ganges-Brahmaputra tidal delta plain. Nature Climate Change 5 (2): 153-157. https://doi.org/10.1038/ nclimate2472.

BanDuDeltAS. 2014. Inception report. Bangladesh Delta plan 2100 formulation project. Dhaka: General Economics Division (GED), Planning Commission, Government of the People's Republic of Bangladesh.

Chapman, A.D., S.E. Darby, H.M. Hồng, E.L. Tompkins, and T.P.D. Van. 2016. Adaptation and development trade-offs: Fluvial sediment deposition and the sustainability of rice-cropping in An Giang Province, Mekong Delta. Climatic Change 137 (3): 593-608. https://doi.org/10.1007/ s10584-016-1684-3.

Church, J.A., P.U. Clark, A. Cazenave, J.M. Gregory, S. Jevrejeva, A. Levermann, M.A. Merrifield, G.A. Milne, R.S. Nerem, P.D. Nunn, A.J. Payne, W.T. Pfeffer, D. Stammer, and A.S. Unnikrishnan. 2013. Sea level change. In Climate change 2013: The physical science basis. Contribution of working group I to the fifth assessment report of the intergovernmental panel on climate change, ed. T.F. Stocker, D. Qin, G.-K. Plattner, M. Tignor, S.K. Allen, J. Boschung, A. Nauels, Y. Xia, V. Bex, and P.M. Midgley. Cambridge/New York: Cambridge University Press.

Coastal Protection and Restoration Authority. 2013. 2017 Coastal master plan. Model improvement plan. Version II (Revised March 2014). Baton Rouge: The Water Institute of the Gulf. http://coastal.la.gov/wp-content/ uploads/2013/09/MIP-Overview-3-12-14.pdf. Accessed 28 Aug 2017.

Dasgupta, S., M. Huq, Z.H. Khan, M.M.Z. Ahmed, N. Mukherjee, M.F. Khan, and K. Pandey. 2014. Cyclones in a changing climate: The case of Bangladesh. Climate and Development 6 (2): 96-110. https://doi.org/10.1080/17565529 .2013.868335. 
Day, J.W., J. Agboola, Z. Chen, C. D’Elia, D.L. Forbes, L. Giosan, P. Kemp, C. Kuenzer, R.R. Lane, R. Ramachandran, J. Syvitski, and A. YañezArancibia. 2016. Approaches to defining deltaic sustainability in the 21 st century. Estuarine, Coastal and Shelf Science 183: 275-291. https://doi. org/10.1016/j.ecss.2016.06.018. Part B.

Delta Commissie. 2008. Working together with water. A living land builds for its future. Findings of the Delta Commissie. The Netherlands: Delta Commissie. http://www.deltacommissie.com/doc/deltareport_full.pdf. Accessed 28 Aug 2017.

Ericson, J.P., C.J. Vorosmarty, S.L. Dingman, L.G. Ward, and M. Meybeck. 2006. Effective sea-level rise and deltas: Causes of change and human dimension implications. Global and Planetary Change 50 (1-2): 63-82. https://doi. org/10.1016/j.gloplacha.2005.07.004.

GED. 2012. Perspective plan of Bangladesh 2010-2021: Making vision 2021 a reality. General Economics Division (GED), Planning Commission. Dhaka: General economics division (GED), Planning Commission, Government of the People's Republic of Bangladesh. http://www.plancomm.gov.bd/perspective-plan/. Accessed 20 July 2016.

empowering citizens. Final draft. Dhaka: General Economics Division (GED), Planning Commission, Government of the People's Republic of Bangladesh. http://plancomm.gov.bd/wp-content/uploads/2015/11/7FYP_afterNEC_11_11_2015.pdf. Accessed 6 Jan 2017.

. 2017. Data gap analysis of sustainable development goals (SDGs): Bangladesh perspective. Dhaka: General Economics Division (GED), Planning Commission, Government of the People's Republic of Bangladesh. http://www.plancomm.gov.bd/perspective-plan/. Accessed 19 Aug 2017.

Hijioka, Y., E. Lin, J.J. Pereira, R.T. Corlett, X. Cui, G.E. Insarov, R.D. Lasco, E. Lindgren, and A. Surjan. 2014. Asia. In Climate change 2014: Impacts, adaptation, and vulnerability. Part B: Regional aspects. Contribution of working group II to the fifth assessment report of the intergovernmental panel on climate change, ed. V.R. Barros, C.B. Field, D.J. Dokken, M.D. Mastrandrea, K.J. Mach, T.E. Bilir, M. Chatterjee, K.L. Ebi, Y.O. Estrada, R.C. Genova, B. Girma, E.S. Kissel, A.N. Levy, S. MacCracken, M.D. Mastrandrea, and L.L. White, 1327-1370. Cambridge, UK: Cambridge University Press.

Huq, S., S.I. Ali, and A.A. Rahman. 1995. Sea-level rise and Bangladesh: A preliminary analysis. Journal of Coastal Research SI 14: 44-53.

Lumbruso, D.M., N.R. Suckall, R.J. Nicholls, and K.D. White. 2017. Enhancing resilience to coastal flooding from severe storms in the USA: 
International lessons. Natural Hazards and Earth Systems Sciences. https://doi. org/10.5194/nhess-17-1-2017.

Milliman, J.D., J.M. Broadus, and G. Frank. 1989. Environmental and economic implications of rising sea level and subsiding deltas: The Nile and Bengal examples. Ambio 18 (6): 340-345.

National Water Development Agency. 2017. National perspectives for water resources development National Water Development Agency, Ministry of Water Resources, Government of India. http://www.nwda.gov.in/index2.asp ?slid=108\&sublinkid=14\&langid=1. Accessed 28 Aug 2017.

Nicholls, R.J., C.W. Hutton, A.N. Lázár, A. Allan, W.N. Adger, H. Adams, J. Wolf, M. Rahman, and M. Salehin. 2016. Integrated assessment of social and environmental sustainability dynamics in the Ganges-BrahmaputraMeghna delta, Bangladesh. Estuarine, Coastal and ShelfScience 183: 370-381. https://doi.org/10.1016/j.ecss.2016.08.017. Part B.

Payo, A., A.N. Lázár, D. Clarke, R.J. Nicholls, L. Bricheno, S. Mashfiqus, and A. Haque. 2017. Modeling daily soil salinity dynamics in response to agricultural and environmental changes in coastal Bangladesh. Earth's Future. https://doi.org/10.1002/2016EF000530.

Prinsen, G., F. Sperna Weiland, and E. Ruijgh. 2015. The Delta model for fresh water policy analysis in the Netherlands. Water Resources Management 29 (2): 645-661. https://doi.org/10.1007/s11269-014-0880-z.

Roy, M., J. Hanlon, and D. Hulme. 2016. Bangladesh confronts climate change: Keeping our heads above water. London: Anthem Press.

Syvitski, J.P.M., A.J. Kettner, I. Overeem, E.W.H. Hutton, M.T. Hannon, G.R. Brakenridge, J. Day, C. Vorosmarty, Y. Saito, L. Giosan, and R.J. Nicholls. 2009. Sinking deltas due to human activities. Nature Geoscience 2 (10): 681-686. https://doi.org/10.1038/ngeo629.

Szabo, S., D. Begum, S. Ahmad, Z. Matthews, and P.K. Streatfield. 2015. Scenarios of population change in the coastal Ganges Brahmaputra Delta (2011-2051). Asia Pacific Population Journal 30 (2): 51-72.

Szabo, S., R.J. Nicholls, B. Neumann, F.G. Renaud, Z. Matthews, Z. Sebesvari, A. AghaKouchak, R. Bales, C.W. Ruktanonchai, J. Kloos, E. FoufoulaGeorgiou, P. Wester, M. New, J. Rhyner, and C. Hutton. 2016. Making SDGs work for climate change hotspots. Environment: Science and Policy for Sustainable Development 58 (6): 24-33. https://doi.org/10.1080/00139157. 2016.1209016.

Tessler, Z.D., C.J. Vörösmarty, M. Grossberg, I. Gladkova, H. Aizenman, J.P.M. Syvitski, and E. Foufoula-Georgiou. 2015. Profiling risk and sustainability in coastal deltas of the world. Science 349 (6248): 638. https://doi. org/10.1126/science.aab3574. Licence. 
UN. 2013. World population prospects, the 2012 revision. Department of Economic and Social Affairs, Population Division. https://esa.un.org/unpd/ wpp/Publications/. Accessed 30 May 2014.

- 2015. Transforming our world: The 2030 agenda for sustainable development. Resolution adopted by the general assembly on 25 September 2015. New York: United Nations.

Van Alphen, J. 2016. The delta programme and updated flood risk management policies in the Netherlands. Journal of Flood Risk Management 9 (4):310-319. https://doi.org/10.1111/jfr3.12183.

Wahl, T., S. Jain, J. Bender, S.D. Meyers, and M.E. Luther. 2015. Increasing risk of compound flooding from storm surge and rainfall for major US cities. Nature Climate Change 5 (12): 1093-1097. https://doi.org/10.1038/nclimate2736.

Warrick, R.A., E.M. Barrow, and T.M.L. Wigley, eds. 1993. Climate and sea level change: Observations, projections, implications. Cambridge: Cambridge University Press.

Whitehead, P.G., E. Barbour, M.N. Futter, S. Sarkar, H. Rodda, J. Caesar, D. Butterfield, L. Jin, R. Sinha, R. Nicholls, and M. Salehin. 2015a. Impacts of climate change and socio-economic scenarios on flow and water quality of the Ganges, Brahmaputra and Meghna (GBM) river systems: Low flow and flood statistics. Environmental Science-Processes and Impacts 17 (6): 1057-1069. https://doi.org/10.1039/c4em00619d.

Whitehead, P.G., S. Sarkar, L. Jin, M.N. Futter, J. Caesar, E. Barbour, D. Butterfield, R. Sinha, R. Nicholls, C. Hutton, and H.D. Leckie. 2015b. Dynamic modeling of the Ganga river system: Impacts of future climate and socio-economic change on flows and nitrogen fluxes in India and Bangladesh. Environmental Science-Processes and Impacts 17 (6): 1082-1097. https://doi. org/10.1039/c4em00616j.

Woodroffe, C.N., R.J. Nicholls, Y. Saito, Z. Chen, and S.L. Goodbred. 2006. Landscape variability and the response of Asian megadeltas to environmental change. In Global change and integrated coastal management: The Asia-Pacific region, ed. N. Harvey, 277-314. Dordrecht: Springer.

World Bank. 2010. Economics of adaptation to climate change : Bangladesh. Volume 1 main report. Washington, DC: World Bank Group. https://openknowledge.worldbank.org/handle/10986/12837. Accessed 09 Jan 2017.

Yasuda, Y., D. Aich, D. Hill, P. Huntjens, and A. Swain. 2017. Transboundary water cooperation over the Brahmaputra River. Legal political economy analysis of current and future potential cooperation. The Hague: The Hague Institute for Global Justice. 
Open Access This chapter is licensed under the terms of the Creative Commons Attribution 4.0 International License (http://creativecommons.org/licenses/ by/4.0/), which permits use, sharing, adaptation, distribution and reproduction in any medium or format, as long as you give appropriate credit to the original author(s) and the source, provide a link to the Creative Commons license and indicate if changes were made.

The images or other third party material in this chapter are included in the chapter's Creative Commons license, unless indicated otherwise in a credit line to the material. If material is not included in the chapter's Creative Commons license and your intended use is not permitted by statutory regulation or exceeds the permitted use, you will need to obtain permission directly from the copyright holder.

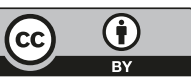

